\title{
Diffusion of Renewable Energy Policy Innovations in Ghana
}

\author{
Leslie Mawuli Aglanu \\ Department of Environmental Governance, Albert-Ludwigs University, Freiburg, Germany \\ Email: mawuli.aglanu@gmail.com
}

Received 1 June 2016; accepted 10 July 2016; published 13 July 2016

Copyright (C) 2016 by author and OALib.

This work is licensed under the Creative Commons Attribution International License (CC BY). http://creativecommons.org/licenses/by/4.0/

\section{(c) (i) Open Access}

\begin{abstract}
The capacities of countries to cope with the challenges presented by global environmental changes vary considerably. The increasing international relations between countries are however bridging the gap with information transfer. Nevertheless, this trend is also seen as a hindrance to national sovereignty and has hence created a need to find a new framework to describe and act on the international arena. Diffusion, a processes which may be the first step towards the emergence of international environmental regimes, has therefore become a complementary approach for global dissemination and governance across a broad range of fields. This research focused on the diffusion of renewable energy policy innovations in Ghana and acknowledges that the diffusion of international regulatory policy innovations depends on a complex interplay of factors. The study reveals that power relations play a strong role in the process. Change agents who engage in voluntary and "power with" relations are more likely to effectively diffuse policy innovations to wider social units.
\end{abstract}

\section{Keywords}

Diffusion, Renewable Energy, Policy, Power, Innovations

Subject Areas: International Relations, Politics

\section{Introduction}

Growth and development are highly dependent on energy and this is portrayed in the interrelationship between energy use, industrialization, economic growth and standard of living [1] [2]. Energy potential within the framework of good governance is an asset in building the infrastructure for sustainable development [3]. Access to an affordable, abundant and consistent energy supply is therefore a key driver for industrialization, improvement in standard of living and economic prosperity [4]-[6]. However, energy generation and supply have severe financial and environmental effects such that unrestrained energy consumption can adversely affect the economy 
and the environment [7] [8]. Although many countries still depend on conventional sources of energy (e.g. coal, fossil fuels and nuclear), efforts are being made to increase the share of renewable energy in the total energy generation and consumption around the world [9] [10]. This is primarily due to the high costs associated with conventional sources of energy such as health hazards, environmental and climatic consequences and adverse economic effects due to foreign policy vulnerabilities for imported fuels [2] [5] [7]. As a result, renewable energy policy innovations have been found by the international community to provide the key for sustainable development whiles meeting the challenges of the increasing demand for energy [9].

\section{Renewable Energy Development}

Worldwide renewable energy contributed only $17 \%$ and $19 \%$ of the world's primary energy consumption in 2004 and 2012 respectively [11] [12]. This shows that renewable energy is awfully under exploited. There is therefore the need to design and adopt innovative policy approaches to harness the massively untapped potential of renewable energy sources. For such ambitions to be realised there is the need for the diffusion of modern renewable energy innovations to all parts of the world, especially in developing countries who urgently need these innovations to advance the development of their economies [13]. The exchange of environmentally friendly cutting-edge hardware and technical know-how among different geographical locations of the world for the purpose of adaptation and use need to be promoted by international organizations and trade. The diffusion of these innovations implies the need for an "appropriate economic environment in which the necessary infrastructures are in place, needed supplies are available, and market and profitability perspectives are adequate" [14]. Although many renewable energy reforms are global in character, they have not been uniformly and adequately diffused. Little research has been done on the diffusion and implementation of renewable energy policy innovations in developing countries, many of whom are facing sever energy crises causing political and economic tension.

In the quest for development, access to affordable and reliable energy services is fundamental to reducing poverty, improving health, increasing productivity, enhancing competitiveness and promoting economic growth in developing countries [15]. Apart from small hydro power plants and wood fuels, the adoption of other sources of renewable energy have been relatively slow and in many developing countries the proportion of the rural population supplied with electricity remains low [16]. The current paradigm of renewable energy research is therefore focusing on the importance and contribution of renewable energy innovations to the development of green economies and their minimal impact on the climate. Reference [17] indicates that one of the central challenges of diffusion research is that it often neglects national policy making processes and hence points out the need for an inclusion of the micro and meso-level perspectives, in this case, of renewable energy policy innovations.

\section{Research Method}

This research adopted a case study approach which is largely used in social science research [18]. In gathering data, 12 expert interviews were conducted through a stratified purposeful sampling technique [19] with the sampling frame being from credible actors in private, public and international organisations within the renewable energy sector of Ghana. The interviews were analyses in tandem with various scientific research articles as well as some governmental documents in the energy sector. The research adopted an exploratory research design since available knowledge is blurry with little understanding with regards to the issue being evaluated [20]. The underpinning theoretical framework of the research is the Diffusion of Innovation Theory [21]. Diffusion research, consequently seeks to explore how factors such as time, attributes of an innovation, nature of the social system into which the innovation is being introduced and how information about the innovation is communicated in the quest of encouraging the adoption of new products, ideas or practices within a social unit [22]. The use of this theory is therefore ideal in analysing how renewable energy policy innovations are defused and how to optimise adoption.

\section{Diffusion and Power Relations}

Although diffusion is a complex system occurring where networks connecting member of a social system are multiple, complex and overlapping, it often occurs in transitional spaces where sufficient differentiation among 
network members exists [23]. Despite this assertion policy innovation diffusion has been relatively slow in developing countries such as Ghana and renewable energy policy innovations is among those least diffused.

In analysing the process, policy diffusion can be categorised into two main paths voluntary and coerced (Figure 1). Various units adopt policy innovations if it presents favourable attributes and promises high returns. Upon observing the outcomes of policies as adopted and applied elsewhere, policy-makers through effective communication are able to assess the efficiency and applicability of such policies to their local systems based on the logic of appropriateness. State and non-state actors within the adopting social system are the main propellers of voluntary policy diffusion through the exhibiting of "power to" [24] thus, the initiative is independently borne by policy-makers within the adopting country.

Partnerships can also be established when local policy-makers make contacts to work with other organisations in mutual understanding. In this scenario, power identified as "power with" which "refers to such processes of finding common ground among diverse interests, developing shared values and creating collective strength by organizing with each other" is exhibited [24] [25]. This form of power subsequently presents a good platform for cooperation, learning and emulation between the originators, change agents and adopters where there is a seemingly balanced power symmetry between each of them allowing for voluntariness thus, consenting them "to question self-perceptions and to actively build up a new awareness" [24].

Coerced policy diffusion occurs when change agents use "power over" to force policy innovations on adopters who will have otherwise not accepted such policy innovations [24]. Various forms of mediation are used to attract adoption but based on the logic of consequence. Developing countries often fall victim to this form of diffusion due to their economic vulnerability. This is obvious in many agreements with international change agents as well as other donor organisations and countries whose aid, mostly in financial forms, play a significant role in economic development thereby giving them an invisible power over the recipient country. Although many international organizations impose policies through the use comparative power relations and advantage [26], others do not focus on "formulating, transferring, selling and teaching not formal regulation, but principled or causal beliefs helping to constrain or enable certain types of social behaviour" [27]. The process of diffusion

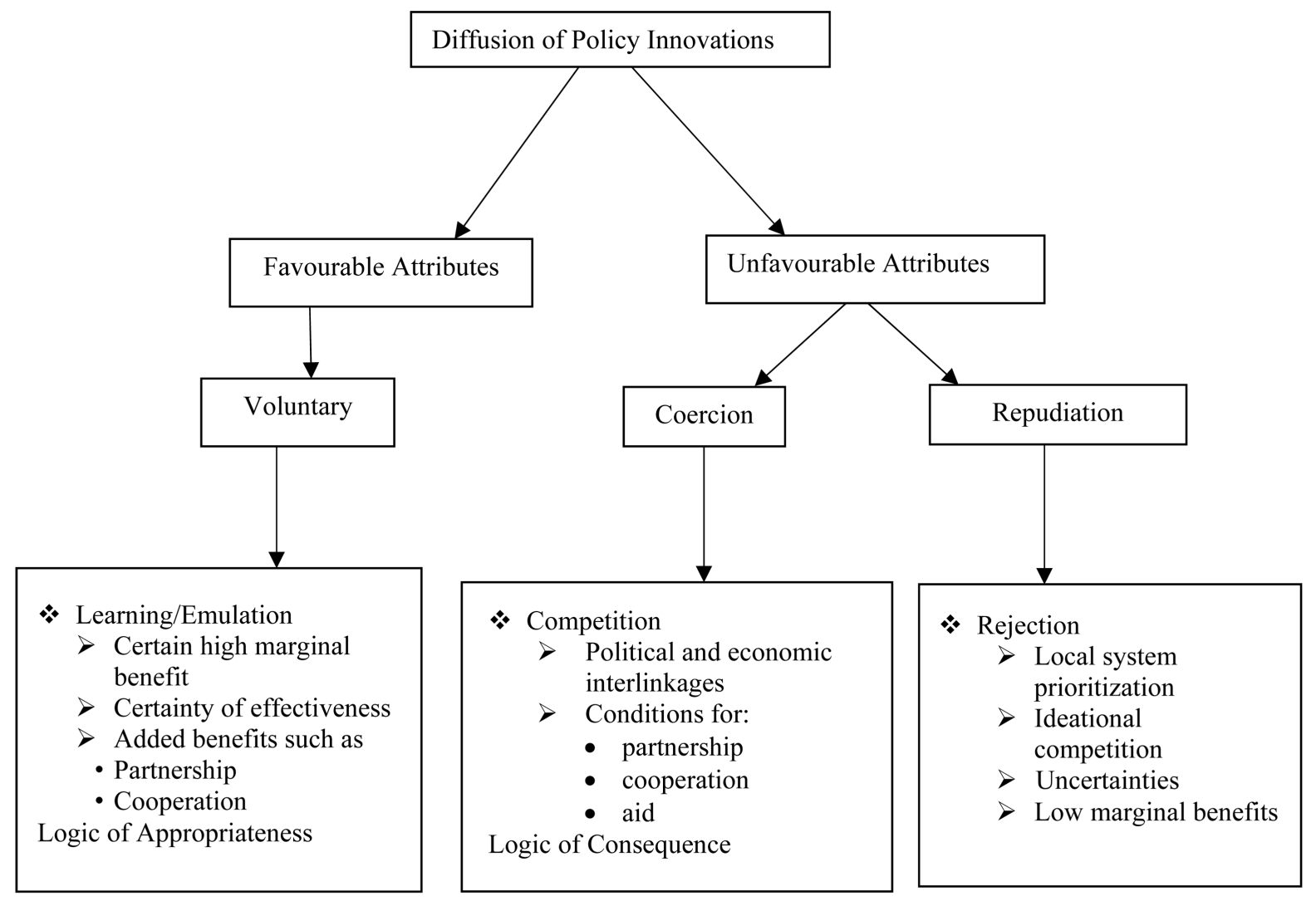

Figure 1. Diffusion of policy innovation framework. 
does not always lead to successful adoption or implementation. Some units or countries are able to resist coercion if the promoted policy innovations are considered unfavourable and infective. They are able to repudiate this form of diffusion and remain as non-adopters by prioritising local policies and vying for policy superiority at international and multi-level settings in order to prevent them from being obliged to implement policies and regulatory schemes that may not match their own administrative structures and policy styles [28]. This is described as ideational and regulatory competition among policy innovators and pioneers [17]. In this regard policy-makers are careful about the anticipated economic and administrative costs and benefits which will result from an increasingly complex political and economic interdependence of other countries legitimacy [29]. This is a representation of the second dimension of the power over asymmetry, "material structuralist power" [24] where the repudiating social unit devotes efforts into creating or reinforcing their policies so as to remain pioneers or prioritise their local systems against others.

\section{Results and Discussion}

\subsection{Energy and Development}

The promulgation of the Renewable Energy Act 832 in 2011 has been hailed as the most concrete regulatory and policy measure in the Ghanaian renewable energy sector. Section one (1) of the Act identifies renewable energy as those sources from wind, solar, hydro (below $100 \mathrm{MW}$ ), biomass, bio-fuel, sewage gas, geothermal energy, ocean energy and any other energy source designated in writing by the Minister (Minister of Power). Generally, the choice of energy sources in Ghana has been a constant topic of debate. The country has a total installed electricity capacity of 2846.5 MW with the main source of energy generated from the Akosombo hydro power plant which generates $1020 \mathrm{MW}$ of electricity. The remaining supply is generated from a number of small thermal and hydro plants including a 2.5 MW installed solar capacity [30] [31]. Despite the 72 percent rate of national electrification as indicated in the 2012 Sustainable Energy for All Action Plan of Ghana, the second highest in Sub-Saharan Africa, constant electricity supply has eluded many Ghanaians.

The rapid growth in electricity demand of about 10\% - 15\% per annum over the last two decades [32] has left the country engrossed in a mesh of an energy crisis culminating in load shedding popularly called "dumsor". This challenge has been attributed to poor planning and lack of proactive measures by the responsible authorities [33]. Specifically the challenges include poor management, finical constraints, fuel shortages, low precipitation and the frequent breakdown of generating facilities. Many of the population have no choice but to rely on traditional fuels from firewood and wood charcoal for their primary energy supply with the associated health, environmental and economic impacts [34]-[36]. On the average, Ghana loses in production worth about US \$2.1 million per day as a result of load shedding. In 2014 the country lost about US \$680 million translating into about 2\% of GDP due to the power crisis [37]. Reference [38] shows that Ghana's real GDP has declined significantly from $8.8 \%$ in 2012 to $4.2 \%$ in 2014 . This trend has been attributed to negative growth in the manufacturing and industrial sectors largely due to the inadequate power supply.

\subsection{Renewable Energy Potentials}

Ghana's renewable energy potential is considered among the best in the West African sub-region. Of the total 1411 MW medium to large scale renewable energy projects identified in the sub-region, about $11.5 \%$ is located in Ghana [39]. Nonetheless, the current total share of renewable energy sources (excluding hydro above 100 MW) in the electricity generation mix in Ghana is about $0.3 \%$ [40]. Renewable energy politics has until recently gained prominence on the national agenda and the government is making efforts towards the adoption and implementation of appropriate renewable energy policy innovations. This is in efforts to exploit the high potential energy crops, forest crops and crop residue for biomass, small and medium hydro power potentials of which 14 sites have been identified with a total capacity of $740 \mathrm{MW}$, high solar irradiation of $4-6 \mathrm{kWh} / \mathrm{m}^{2} /$ day and wind energy potentials (Figure 2) [41].

Recent power crisis in the country impelled a review of the long-term electricity policy by the Government and the Volta River Authority (VRA) in terms of the electricity generation mix required for national investments and long term needs [32]. Currently, Ghana is among the few members countries of the Economic Communities of West African States (ECOWAS) that have included renewable energy integration in its energy policy [42]. The Energy Commission of Ghana (EC) and the Ghana Energy Development and Access Project (GEDAP) have 


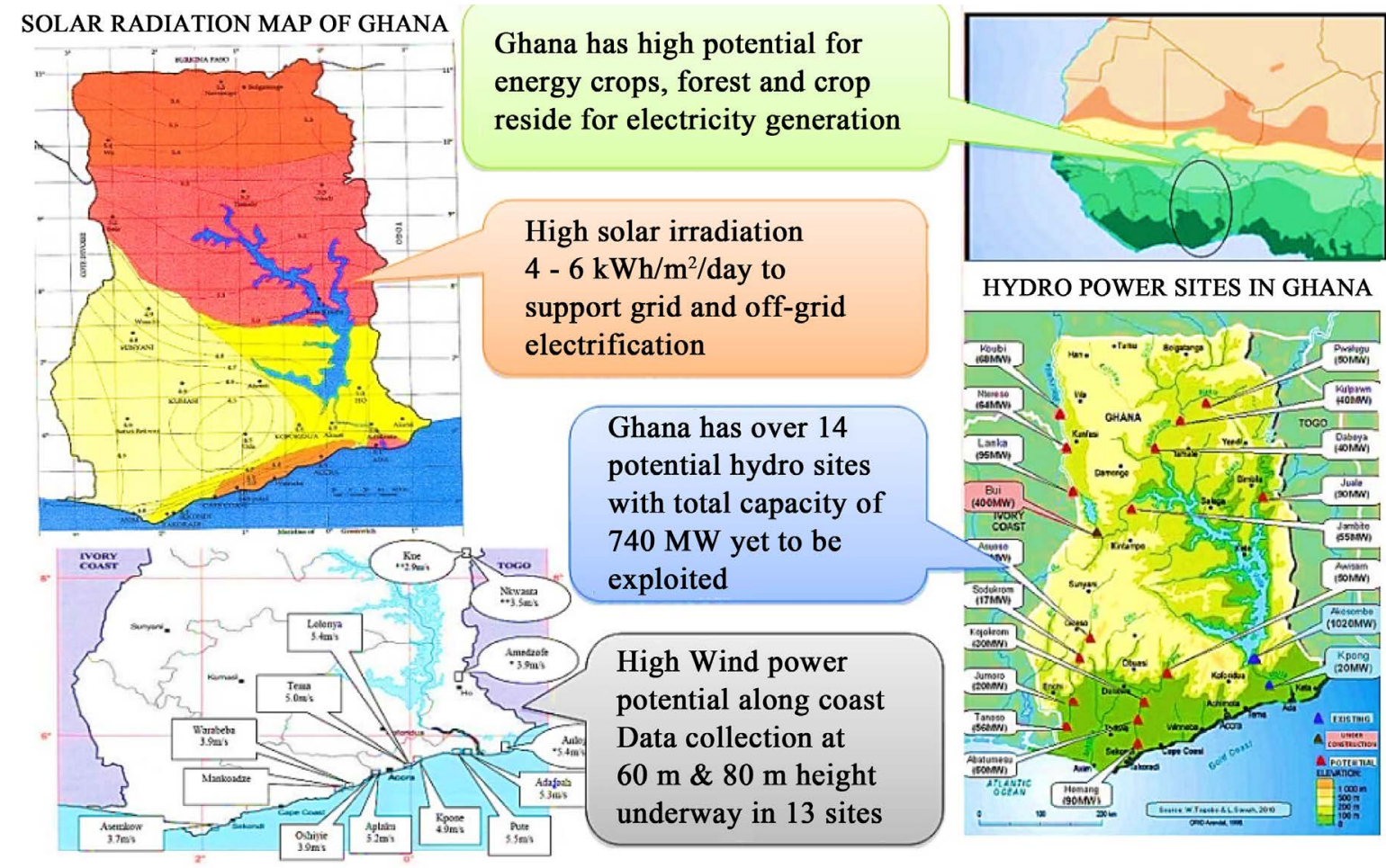

Figure 2. Renewable Energy Resource Potential in Ghana.

been playing key roles in advocating renewable energy exploitation using modern technologies in the Sub-Saharan African region [36].

\subsection{The Current Paradigm of Renewable Energy}

In analysing the state of renewable energy in the country, the interviews demonstrated a mixed outlook on its assessment, particularly grid connected renewables. There was some skewness in the responses as many of the experts from the public sector presented a more positive assessment whiles experts from the private sector were more sceptical. All the interviewees however acknowledged that the country is still at the early stage of adopting contemporary renewable energy innovations. As depicted in Figure 3 below, the trend of energy generation by source between 2005 and 2014 shows that the country has put much effort into thermal power due to its cheap and quick returns. Under the period of review, the data shows that the percentage increase in hydro generation was 32.88 percent and that of thermal generation 74.65 percent. For renewables, solar was only made available in 2013 and 2014 generating 3 and 4 GW respectively representing an increase in generation by 25 percent. Renewables therefore had the smallest marginal increase among the three generation sources.

The total installed generation capacity increased by 38.89 percent whiles the total actual generation increased by 47.64 percent. If average annual demand is increasing by 10 percent then these figures clearly indicate that the deficit in the supply of energy will continue to prevail unless generation and supply increase in tandem with demand. The slow growth of renewables in the share of the Ghanaian energy mix as indicated above was re-echoed by many of the interviewees, particular from the private sector. This trend have also been criticised by many scholars [1] [32] [34] [36] who described it as highly resting on the poor level of technological applications and insufficient energy infrastructural development to cater for the sustainable use of renewable energy resources. On the other hand, most of the interviewees from the public sector were quite optimistic and pointed out that there have been some progress over the years to actively explore renewables as an alternative source of energy generation and that the promulgation of the Renewable Energy Act is a proof of that.

\subsection{Renewable Energy Diffusion in Ghana}

Even though Ghana is a member of many international organisations supporting a clean environment, the drive 


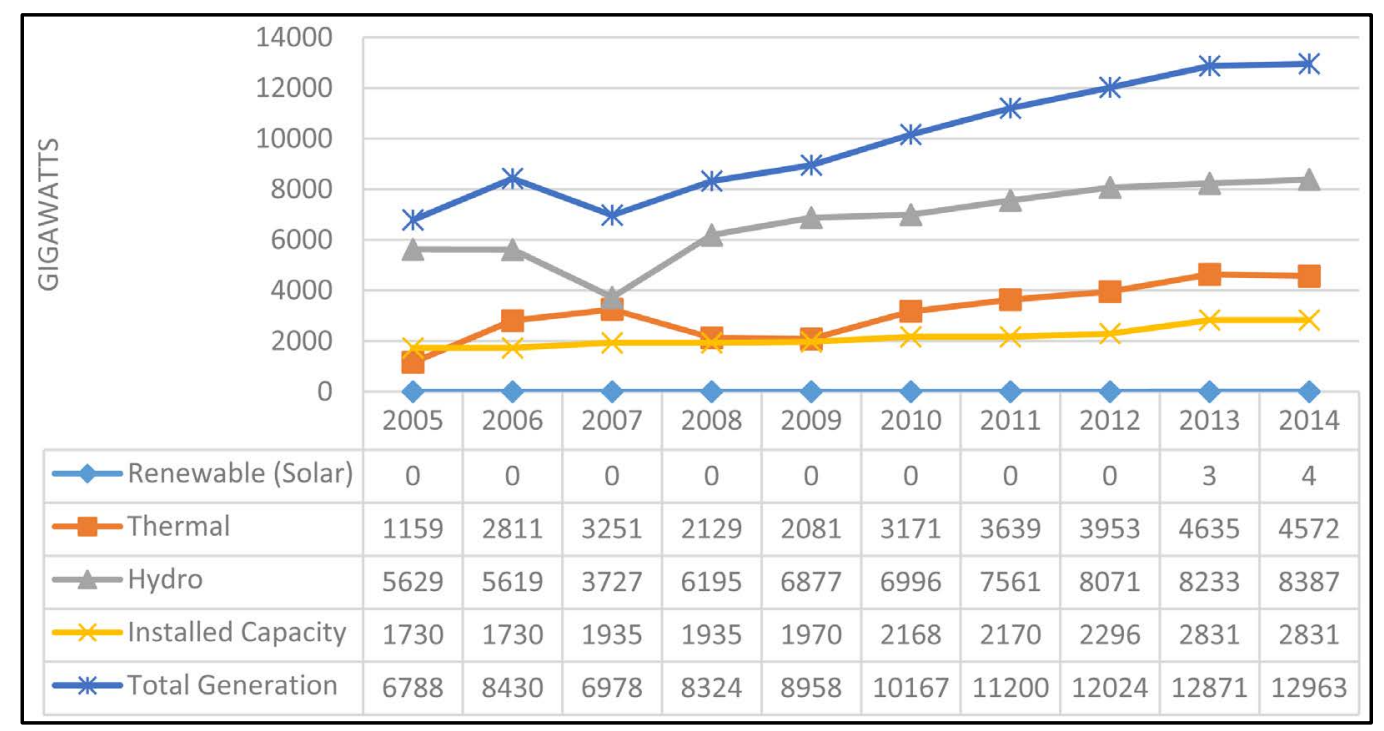

Figure 3. Trend in electricity generation by source.

for renewables was self-motivated. It was noted that with a high political commitment, Ghana is taking a keen interest in tandem with the new world order of promoting clean energy and climate change mitigation actions. The main motive for Ghana's interest in renewables however is to harness this source as an alternative power generation source and subsequently secure the energy sector. In the process of adopting renewable energy policy innovations, policy-makers in Ghana are committed and act rationally by looking across borders for effective solutions to the pressing domestic energy problems [43] [44]. This represents a voluntary form of adoption where Ghana is exhibiting the "power to" adopt and implement such policies [24]. It was generally agreed by the interviewees that there is virtually no form of external pressure rather, Ghanaians are enthused and ready to embrace renewable energy. They however pointed out the fact that it is left with the government to put in place strong policy frameworks and regulations as well as provide incentives to attract investments in the sector.

Despite these assertions, Ghana has been externally influenced to a certain extend in the development of its renewable energy policies. Ghanaian experts in the sector took the initiative of consulting other countries such as Germany, the United Kingdom, Australia, India, Spain, and South Africa. They also participated in various international renewable energy conferences in order to learn and adopt ideas applicable to the Ghanaian condition. This is a very important part of any diffusion process as pointed out by many diffusion scholars [17] [21] [26] [28] [44] who analysed the importance of studying the effects and implications of such policy innovations as applied elsewhere. By extending a hand for assistance, Ghana identified the need to learn from the world's experts and leading countries in the field. This is a demonstration of "power with" whereby Ghana creates collective strength, develop shared values and find common ground among diverse interests in the field of renewable energy [24]. The opening up of Ghana to the diffusion of renewable energy innovations has paved way for other opportunities in the sector. Contributions from both domestic and international actors which influences the sector, as indicate by the interviewees, include investments, partnership, research, financial assistance and technical assistance in the formulation of policy frameworks and regulations. However, the commercialization and harmonisation of the Ghanaian renewable energy atmosphere requires adequate institutional support and a strong coordination among institutions involved in order to attract investments as well as promote the diffusion process [45] [46].

\section{Redirecting the Course of Diffusion}

In order to attain socio-economic progress, the need to come up with appropriate policy innovations by developing countries, such as Ghana, have to consider their factor proportions, level of development and development strategies. This may either be the diffusion of intermediate small-scale or modern large-scale capital intensive innovations. Obviously the process of diffusion does not necessarily lead to final adoption and confirmation if measures that require constant attention such as skill training and research are not effectively undertaken to fur- 
ther develop the ability of producing new policy innovations that will eventually lead to self-reliance. The creation of a capable indigenous renewable energy policy innovation in developing countries will inevitably involve some influence from the diffusion process. A well planned strategy is therefore essential in maximising the benefits of the diffusion process so that it does not result in the dependence on foreign policies. To ensure effective diffusion of renewable energy policy innovations change agents should avoid coercion which often leads to perverse outcomes and focus on voluntary policy diffusion mechanism by establishing networks of free information and communication flow where all actors involved will have access.

In summary, the study does not suggest that the categories of policy innovation diffusion identified herein are mutually exclusive. Rather they are complex with multiple aspects of overlaps occurring within transitional spaces. In effect, young and emerging countries in the field of renewable energy policy innovations need to be careful not to make biased decisions due to prior beliefs and ideologies which can make rational learners subject to confirmation bias. National priorities should be direct and specifically set. Policy-makers should also focus on policy innovation options that promise the highest level of effectiveness with low economic and administrative costs so as to avoid an increasing complex political and economic interdependence on other countries.

\section{Acknowledgements}

I will like to express my profound gratitude to PD Dr. Lena Partzsch and Prof. Markus Lederer for their constructive criticisms, annotations and suggestions as well as all my interviewees for sharing valuable information leading to the success of this research.

\section{References}

[1] Bugaje, I.M. (2006) Renewable Energy for Sustainable Development in Africa: A Review. Renewable and Sustainable Energy Reviews, 10, 603-612.

[2] Greenstone, M. and Looney, A. (2012) Paying Too Much for Energy? The True Costs of Our Energy Choices. Dredalus, the Journal of the American Academy of Arts \& Sciences, 141, 10-30.

[3] Khennas, S. (2012) Understanding the Political Economy and Key Drivers of Energy Access in Addressing National Energy Access Priorities and Policies: African Perspective. Energy Policy, 47, 21-26.

[4] Dincer, I. and Rosen, A.M. (1999) Energy, Environment and Sustainable Development. Applied Energy, 64, 427-440.

[5] Omer, M.A. (2008) Energy, Environment and Sustainable Development. Renewable and Sustainable Energy Reviews, 12, 2265-2300.

[6] Kebede, E., Kagochi, J. and Jolly, M.C. (2010) Energy Consumption and Economic Development in Sub-Sahara Africa. Energy Economics, 32, 532-537.

[7] Dincer, I. (2000) Renewable Energy and Sustainable Development: A Crucial Review. Renewable and Sustainable Energy Reviews, 4, 157-175.

[8] Ministry of Energy (2006) Energy for Poverty Reduction Action Plan for Ghana. A Targeted Approach to Delivery of Modern Energy Services to the Poor. Ministry of Energy, Accra.

[9] Painuly, J.P. and Fenhann, J.V. (2002) Implementation of Renewable Energy Technologies—Opportunities and Barriers: Summary of Country Studies. UNEP Collaboration Centre on Energy and Environment. Riso National Laboratory, Denmark.

[10] Strupeit, L. and Palm, A. (2016) Overcoming Barriers to Renewable Energy Diffusion: Business Models for CustomerSited Solar Photovoltaics in Japan, Germany and the United States. Journal of Cleaner Production, 123, 124-136.

[11] Renewable Energy Policy Network (REN21) (2005) Renewables 2005 Global Status Report. Worldwatch Institute, Washington DC.

[12] Renewable Energy Policy Network (REN21) (2014) Renewables 2014 Global Status Report (Paris: REN21 Secretariat).

[13] Hoekman, B.M., Maskus, K.E. and Saggi, K. (2005) Transfer of Technology to Developing Countries: Unilateral and Multilateral Policy Options. World Development, 33, 1587-1602.

[14] Able-Thomas, U. (1996) Models of Renewable Energy Technology Transfer to Developing Countries. Renewable Energy, 9, 1104-1107.

[15] International Energy Agency (2016) Modern Energy for All: Why It Matters. http://www.worldenergyoutlook.org/resources/energydevelopment/modernenergyforallwhyitmatters/ 
[16] Urmee, T., Harries, D. and Schlapfer, A. (2009) Issues Related to Rural Electrification Using Renewable Energy in Developing Countries of Asia and Pacific. Renewable Energy, 34, 354-357. http://dx.doi.org/10.1016/j.renene.2008.05.004

[17] Tews, K. (2005) The Diffusion of Environmental Policy Innovations: Cornerstones of an Analytical Framework. European Environment, 15, 63-79. http://dx.doi.org/10.1002/eet.378

[18] Gerring, J. (2007) Case Study Research: Principles and Practices. Cambridge University Press, Cambridge.

[19] Onwuegbuzie, J.A. and Leech, L.N. (2007) A Call for Qualitative Power Analyses. Quality and Quantity, 41, $105-121$. http://dx.doi.org/10.1007/s11135-005-1098-1

[20] Yin, R.K. (2003) Case Study Research: Design and Methods. 3rd Edition, Sage, Thousand Oaks.

[21] Rogers, E.M. (2003) Diffusion of Innovations. 5th Edition, the Free Press, New York.

[22] Surry, D.W. and Farquhar, J.D. (1997) Diffusion Theory and Instructional Technology. Journal of Instructional Science and Technology, 2, 24-36.

[23] Rogers, E.M., Medina, U.E., River, M.A. and Wiley, C.J. (2005) Complex Adaptive Systems and the Diffusion of Innovations. The Innovation Journal: The Public Sector Innovation Journal, 10, 579-584.

[24] Partzsch, L. and Fuchs, D. (2012) Philanthropy: Power with in International Relations. Journal of Political Power, 5, 359-376. http://dx.doi.org/10.1080/2158379X.2012.735114

[25] Haugaard, M. (2011) Editorial. Journal of Political Power, 4, 1-8. http://dx.doi.org/10.1080/2158379X.2011.560011

[26] Dolowitz, D.P. and Marsh, D. (2000) Learning from Abroad: The Role of Policy Transfer in Contemporary Policy-Making. Governance, 13, 5-24. http://dx.doi.org/10.1111/0952-1895.00121

[27] Marcussen, M. (2001) The OECD in Search of a Role: Playing the Idea Game. European Consortium for Political Research (ECPR), 29th Joint Session of Workshops, Grenoble, 6-11 April 2001.

[28] Busch, P., Jörgens, H. and Tews, K. (2004) The Global Diffusion of Regulatory Instruments: The Making of a New International Environmental Regime. European Integration Online Papers (EIoP), 8.

[29] Butler, M.D., Volden, C., Dynes, A. and Shor, B. (2015) Ideology, Learning, and Policy Diffusion Experimental Evidence. American Journal of Political Science. http://dx.doi.org/10.1111/ajps.12213

[30] Volta River Authority (2016) Power Generation: Facts \& Figures. http://www.vraghana.com/resources/facts.php

[31] Energy Commission (2014) National Energy Statistics 2000-2013. Final Draft, Strategic Planning and Policy Division, Ghana.

[32] Kemausuor, F., Obeng, Y.G., Brew-Hammond, A. and Duker, A. (2011) A Review of Trends, Policies and Plans for Increasing Energy Access in Ghana. Renewable and Sustainable Energy Reviews, 15, 5143-5154. http://dx.doi.org/10.1016/j.rser.2011.07.041

[33] Amoako-Tuffour, J. and Asamoah, J. (2015) “Thinking Big” and Reforming Ghana’s Energy Sector. Submitted to the African Centre for Economic Transformation. Ghana Transformation Forum, Accra, 10 and 11 February 2015.

[34] Brew-Hammond, A. and Kemausuor, F. (2009) Energy for all in Africa-To Be or Not to Be?! Current Opinion in Environmental Sustainability, 1, 83-88. http://dx.doi.org/10.1016/j.cosust.2009.07.014

[35] Agbemabiese, L., Nkomo, J. and Sokona, Y. (2012) Enabling Innovations in Energy Access: An African Perspective. Energy Policy, 47, 38-47. http://dx.doi.org/10.1016/j.enpol.2012.03.051

[36] Mohammed, Y.S., Mustafa, M.W. and Bashir, N. (2013) Status of Renewable Energy Consumption and Developmental Challenges in Sub-Sahara Africa. Renewable and Sustainable Energy Reviews, 27, 453-463. http://dx.doi.org/10.1016/j.rser.2013.06.044

[37] Ackah, C. (2015) Electricity Insecurity and Its Impact on Micro and Small Businesses in Ghana. Institute of Statistical Social and Economic Research (ISSER), University of Ghana, Accra.

[38] Energy Commission (2015) 2015 Energy (Supply and Demand) Outlook for Ghana.

[39] Lugmayr, M. (2011) ECREEE Strategy to Promote Renewable Energy and Energy Efficiency Investments in the ECOWAS (2011 to 2016). SWAC/OECD Meeting, Praia, 5-6 December 2011.

[40] Ministry of Power (2015) Scaling-Up Renewable Energy Program in Ghana (SREP). Investment Plan.

[41] Buah, E.A.K. (2014) Renewable Energy in Ghana: Policy and Potential. UNEF Spanish Solar Forum, Madrid, 18-19h November 2014.

[42] Gyamfi, S., Modjinou, M. and Djordjevic, S. (2015) Improving Electricity Supply Security in Ghana-The Potential of Renewable Energy. Renewable and Sustainable Energy Reviews, 43, 1035-1045. http://dx.doi.org/10.1016/j.rser.2014.11.102

[43] Stone, D. (2000) Non-Governmental Policy-Transfer: The Strategies of Independent Policy Institutes. Governance, 13, 
45-70. http://dx.doi.org/10.1111/0952-1895.00123

[44] Bender, K., Keller, S. and Willing, H. (2014) The Role of International Policy Transfer and Diffusion for Policy Change in Social Protection-A Review of the State of the Art. IZNE Social Protection Working Paper 14/1, International Policy Learning and Policy Change: Scientific Inputs for the Dialogue on Social Protection with Global Partners.

[45] Amigun, B., Sigamoney, R. and von Blottnit, H. (2008) Commercialization of Biofuel Industry in Africa: A Review. Renewable and Sustainable Energy Reviews, 12, 690-711. http://dx.doi.org/10.1016/j.rser.2006.10.019

[46] Chaurey, A., Krithika, P.R., Palit, D., Rakesh, S. and Sovacool, K.B. (2012) New Partnerships and Business Models for Facilitating Energy Access. Energy Policy, 47, 48-55. http://dx.doi.org/10.1016/j.enpol.2012.03.031

- Publication on a daily basis

- 9 subject areas of science, technology and medicine

- Fair and rigorous peer-review system

- Fast publication process

- Article promotion in various social networking sites (LinkedIn, Facebook, Twitter, etc.)

- Widely-targeted and multidisciplinary audience to read your research

Submit Your Paper Online: Click Here to Submit

Contact Us: service@oalib.com 